\title{
Archaeological Sites in the Labrador-Ungava Peninsula: Cultural Origin and Climatic Significance
}

\author{
BARRY MATTHEWS ${ }^{1}$
}

\begin{abstract}
Ruins of structures in Arctic Quebec and Labrador were investigated, all apparently less than 1,500 years old and abandoned by their Eskimo inhabitants more than 150 years ago. Similar-sized rectangular foundations at two sites near former sea level probably belong to the Thule culture. That their occupants were in contact with Europeans at one time is suggested by the shapes of the foundations and the presence of carved and nailed artefacts. From radiocarbon dating of fossilized animal bones, it is concluded that some of the structures were occupied during a mild period 600-700 years ago. Climate and vegetation of that period were reconstructed from pollen analysis and fossil remains.
\end{abstract}

RÉSUMÉ. Sites archéologiques dans la Péninsule du Labrador-Ungava: Origine culturelle et signification climatique. Des ruines des structures dans l'Arctique du Québec et dans le Labrador ont été étudiées, toutes apparemment vieilles de moins de 1,500 ans et abandonnées de leurs habitants esquimaux il y a plus de 150 ans. Des fondations rectangulaires de dimensions similaires, sur deux sites près de l'ancien niveau de la mer, ont probablement appartenu à la culture thulée. D'après la forme des fondations et la présence d'artefacts taillés et cloués, il semblerait qu'il y ait eu contact entre les habitants et l'Europe à un moment donné. On conclut, à partir de la datation d'ossements fossilisés d'animaux par procédé au radiocarbone, que certaines de ces structures avaient été occupées il y a 600-700 ans, pendant une période tempérée. Le climat et la végétation de cette période ont été reconstitués à partir d'analyse du pollen et de restes de fossiles.

РЕЗЮМЕ. Археологические изыскания на n-ве Лабрадор-Унаава: происхождение культуры и роль климата. В арктическом Квебеке и на Лабрадоре было проведено обследование остатков сооружений менее уем полуторатысячелетней давности, покинутых әскимосами свыше 150 лет назад. Сходные по величине прямоугольные основания, нанденные в двух местах недалеко от прежнего уровня моря, относятся, вероятно, к периоду тулийской культуры. То, что живпие вдесь люди имели в какой-то период связи с европейпами, видно по форме оснований и по наличию резных и сбитых гвоздями предметов обихода. Датировка окаменелых костей животных радиоуглеродным методом повволяет заключить, что некоторые из сооружений были обитаемы в периоц потепления 600-700 лет назац. Климат и растительность атого периода были воспроивведены путем анализа пыльцы и остатков ископаемых.

\section{INTRODUCTION}

Archaeological sites apparently less than 1,500 years old, and lacking artefacts, have been largely ignored by archaeologists working in Ungava and Labrador. Structures along the Labrador coast were cursorily examined by Mathiassen (1928) and Gathorne-Hardy $(1922,1932)$, but the most detailed reports available on them are those of Wenner (1947) and Tanner (1941) for Sculpin Island. Unfortunately, radiocarbon dating was not known at the time this work was carried out, so that no

1Beacon View, Ellonby, Skelton, Penrith, Cumbria CA11 9SJ, England. 
definite conclusions about the date and origin of the ruins could be reached. Lee (1967a, b, 1968, 1969) and Plumet (1969) examined structures at Fort Chimo, Payne Bay and other sites in Ungava, but Lee's conclusions concerning their age and Norse origin were based on only meagre evidence. What is needed is conclusive proof from radiocarbon-dated Norse artefacts and skeletons, but none to my knowledge has yet been found. In the absence of such positive evidence, therefore, one has to turn to other methods of interpreting the ruins; and it therefore seems pertinent for me, as an ecologist, to present evidence of the climate and vegetation likely to have existed when the settlements were established.

During geomorphological field work in Ungava in the summers of 1961, 1962 and 1965 , I examined several previously unrecorded archaeological sites, while in 1971 I investigated a site on Sculpin Island, North Labrador, first reported by Tanner (1941), and collected samples from it for radiocarbon dating. The locations of these sites are indicated on Fig. 1.

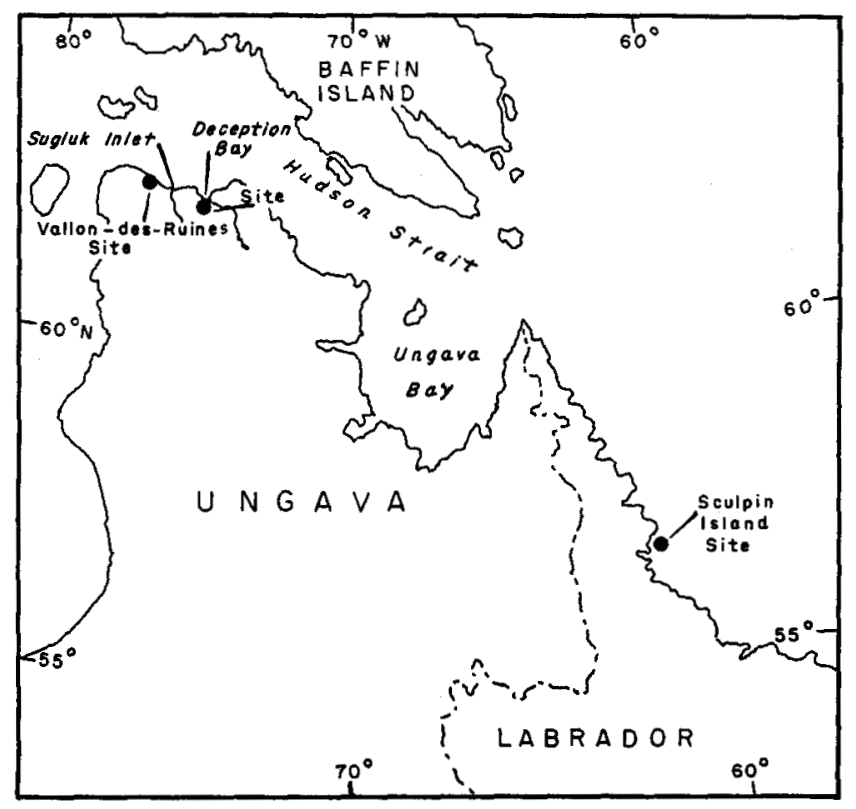

FIG. 1. Location of archaeological sites.

\section{DECEPTION BAY SITES}

The three groups of foundations are indicated in Fig. 2. These include what Lee (1967b) called the Thurston site and the A. L. Penhale site. I first saw part of Group 3 foundations in 1962. At the suggestion of W. E. Taylor, Jr. of the National Museum of Canada, I examined the three groups of foundations in 1965 with S. Phillips (now Dr. Hicks) and A. Fincham, members of the Leeds University Arctic Ungava Expedition which I was leading. Groups 1 and 2 were known from the air to bush pilots who regarded them as being of Dorset cultural origin. Taylor (personal communication, 1964) stated that he examined the site in 1958 and tested several areas while looking for a kitchen midden, but was unable to find one, or 


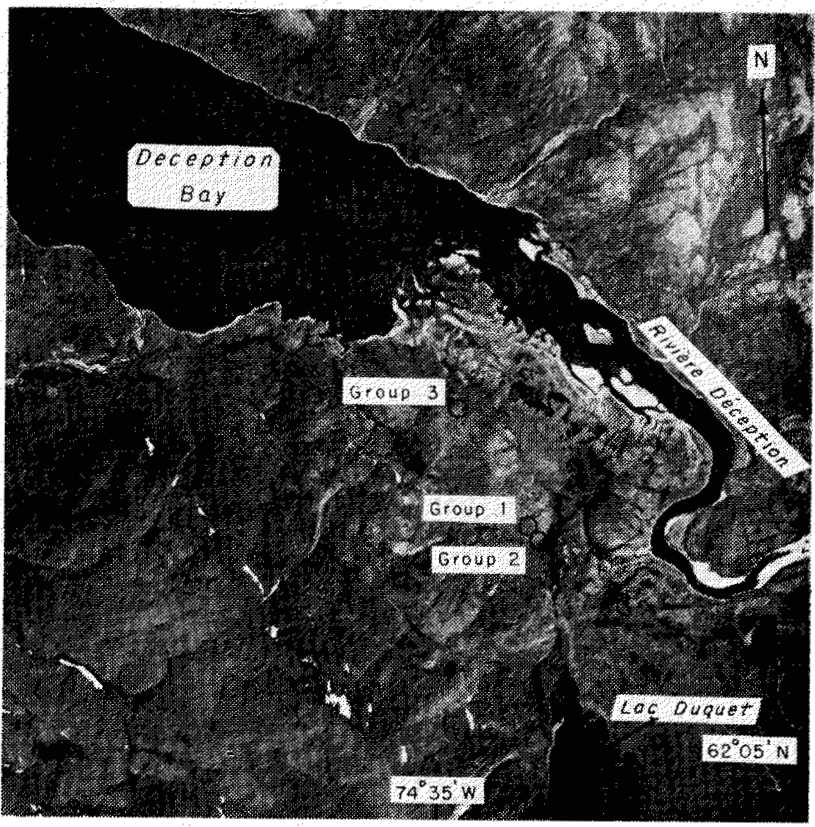

FIG. 2. Location of sites at Deception Bay.

any Eskimo artefact. The considerable development of lichen on the rocks of the stone structures indicated, in his view, that the ruins were old. It would appear, however, that he never saw the beehive structure in which I found artefacts (see below), nor examined the site in detail. It is likely, therefore, that the following account constitutes the first detailed report on the three Deception Bay sites. I have made brief reference to them earlier (Matthews 1967), but only on account of their geomorphological significance. Lee (1967b) briefly described the sites, following a cursory examination of them in 1965.

As no member of my 1965 team was a trained archaeologist, the work in that year took the form of a descriptive survey. Only a few trial holes were dug in the soil outside the stone structures near those already dug by an unknown person (probably W. E. Taylor, Jr.). A map was prepared with the aid of a theodolite to show the relative position of each structure and its relationship to the general topography. In Fig. 3 is indicated the distribution of the Group 1 and Group 2 structures. Measurements and photographs were taken of each structure. Many cracked animal bones were collected from crevices in the ruins, identified by Judith King of the Department of Zoology of the British Museum in 1966 (Appendix 1) and radiocarbon-dated in Japan. My extensive surveys in 1961, 1962 and 1965 did not reveal other archaeological sites with pentagonal and rectangular foundations between Deception Bay and Cape Wolstenholme.

\section{Regional setting}

Deception Bay is at the northern tip of the Labrador-Ungava peninsula within a tundra zone having continuous permafrost. Snow persists throughout the year, but only in patches, as winter snowfall is low. The nearest Eskimo village is Sugluk, $60 \mathrm{~km}$ to the west. Most of the surrounding area consists of an upland erosion 


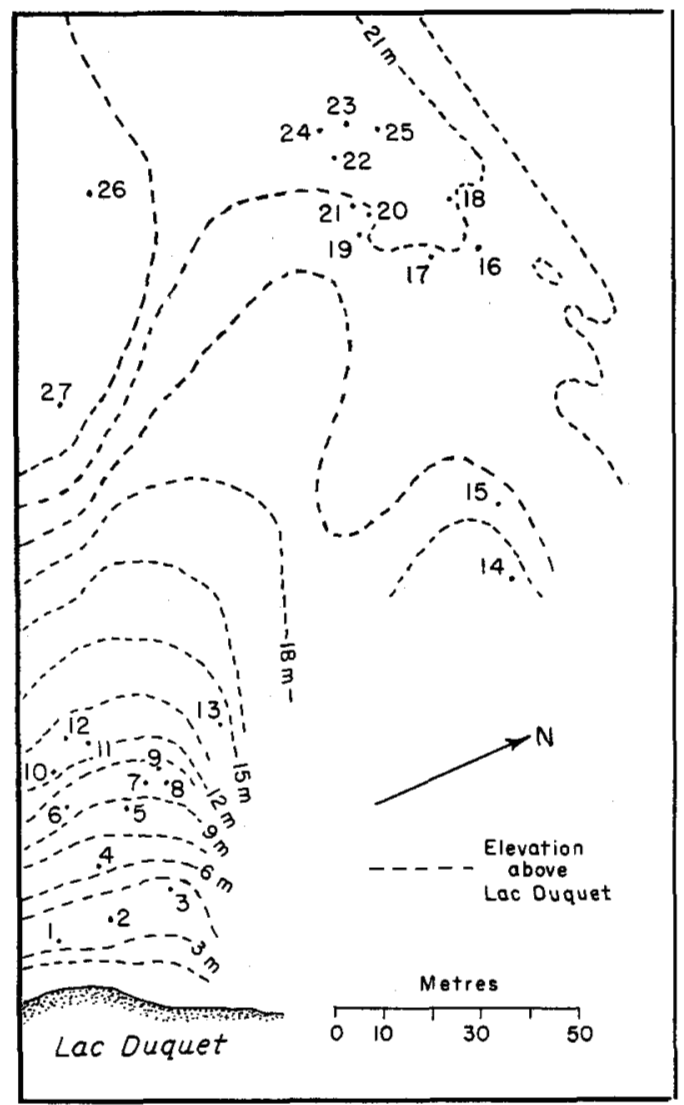

FIG. 3. Distribution of Group 1 and Group 2 structures at Deception Bay.

\section{Group 2}

1, 2, 3 Recent Eskimo tent rings

4 Square foundation

5 Square foundation with dividing walls

6 Pentagonal foundations

7 Square foundations with dividing walls and alcove

8 Square foundations

9 Cache

10 Pentagonal foundations with

11, 12 Cache dividing walls

13 Structure against rock face

Group 1

14 Two walls against rock face and cache

15 Circular foundations against rock face

16, 17 Circular foundations

18 Two stone pillars

19 Circular foundation

20 Circular foundation connected to no. 19 by small cache

21, 22 Elongated foundation

23 Oval foundation with collapsed elongation and human bones

24 Indistinct circular group of stones

25, 26 "Coffin-like" stone fall-trap

27 Vertical stone on hill top

surface at $450-700$ metres, which is terminated in the north by a cliff-line forming an obstacle to access into the interior from the direction of Hudson Strait. Deception Bay, a fiord, is one of the main indentations and access routes. The area has a cold desert-like climate and a sparse tundra vegetation. Vegetation in greater abundance exists on the floor of some of the deeper inland valleys where willow up to five metres tall, and dwarf birch up to one metre tall, are to be found (Maycock and Matthews 1966).

The stone structures are situated $0.6 \mathrm{~km}$ inland on northwest-southeasttrending granite-gneiss rock drumlins about 30 metres above sea level, west of the lagoon area, at the confluence of the river flowing out of Lac Duquet and Rivière Déception $\left(74^{\circ} 31^{\prime} \mathrm{W}, 62^{\circ} 06^{\prime} \mathrm{N}\right)$. The lowest structure is about four metres above present-day sea level. The outlet stream is too shallow, even during spring thaw, to permit of travel by kayak from the ruins to the open sea. Fossiliferous marine deposits occur, however, along the sides of the U-shaped valley of Lac Duquet, a rock-gouged basin ( 30 metres deep at least) and up to 100 metres above present sea level. The deposits serve to indicate that it was once a fiord extension of Deception Bay. The radiocarbon-dated shells (Matthews 1967) from the highest fossiliferous marine deposits in the small valley of Rivière-aux-Roches at the head of Lac Duquet provide proof that it became a fiord extension of Deception Bay at 


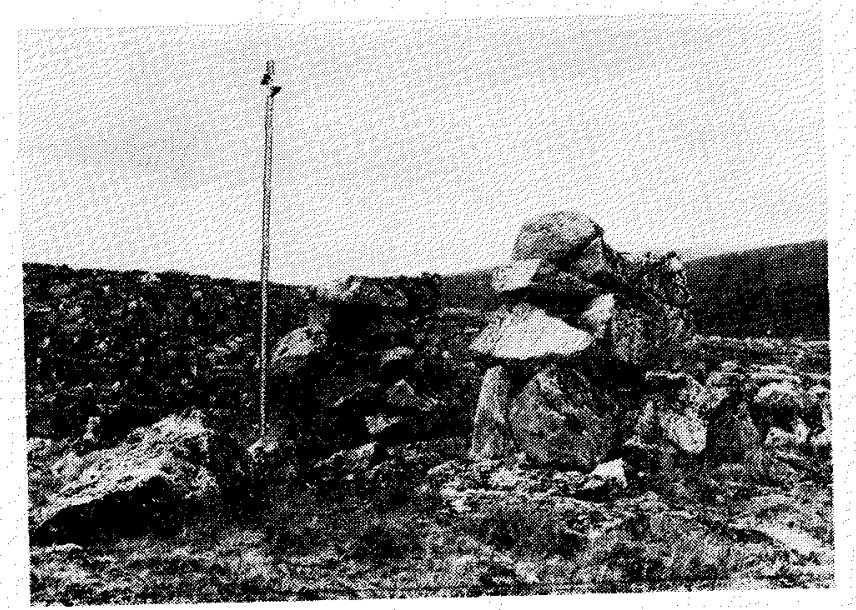

FIG. 4. Structure no. 18, Group 1 site, Deception Bay. The two stone pillars are possible supports for a kayak. Photograph by A. Fincham.

least 6,760 \pm 140 years ago (National Physical Laboratory, England, no. 82). The land uplift curve for the region (Matthews 1967) indicates that glacio-isostatic uplift and siltation caused the Lac Duquet valley to become separated from the sea less than 500 years ago.

\section{Archaeological remains}

\section{Group 1}

This consists of eight oval or circular stone house structures up to three metres in diameter - a few with collapsed tunnel-like entrances. They are situated on the crest of the rock drumlin at an elevation of 30 metres in an area strewn with angular and sub-angular granite-gneiss boulders. A few of the foundations have more than one oval or circular chamber. In front of structure no. 18 are two lichenencrusted one-metre-tall stone pillars 1.5 metres apart (Fig. 4) which were possibly used to support a kayak. There are also a number of fox traps like those described by Lee (1967b). Structure no. 23 (Fig. 5) has internal dimensions $2.5 \mathrm{~m} \mathrm{x} 3.0 \mathrm{~m}$. and is more oval in shape than are structures of Group 2. The walls are of partlyhewn stones; in the eastern wall is a tunnel-like section with a stone floor and part of the roof still in position. On the floor were found the disintegrating bones of a human skeleton partly covered with lichen. Because the skull was missing, it was not possible to determine whether it was European or Eskimo (see Appendix 2).

All man-moved stones were found covered with lichen. A considerable age is indicated by the large size of the thalli of Rhizocarpon geographicum. Because the thalli merged with one another, and because it is not known if they existed on the stones before they were used by man for the dwellings, they cannot be used for the purposes of accurate dating.

\section{Group 2}

This is a cluster of seven pentagonal-, square- and rectangular-shaped stone foundations and three rocky heaps containing animal bones, possibly former meat caches, in a depression trending down the hillside of the same rock drumlin as the 


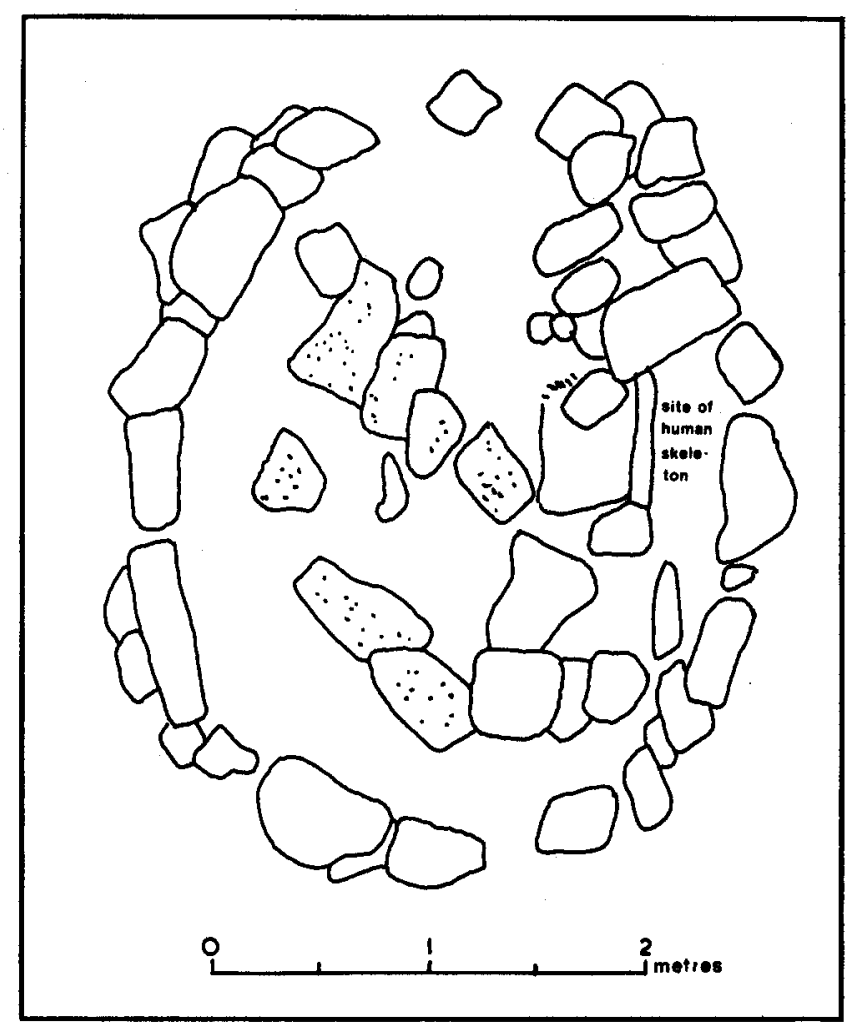

FIG. 5. Plan of structure no. 23, Group 1 site, Deception Bay. The tunnel section was used as a burial chamber at one time.

Group 1 structures. The inside dimensions of the Group 2 house structures are up to $2.4 \mathrm{~m} \mathrm{x} 5.1 \mathrm{~m}$. The walls have large boulders of up to 0.75 metres in diameter piled to a height of up to one metre; some are roughly rectangular, and in the case of structure no. 6 (Fig. 6) incorporate within the base large stones which are part of the bedrock. One corner of structure no. 6 has up to four layers of stones. The pentagonal structures in the depression have a row of flat stones dividing them into two chambers. There are numerous cracked animal bones in crevices between the

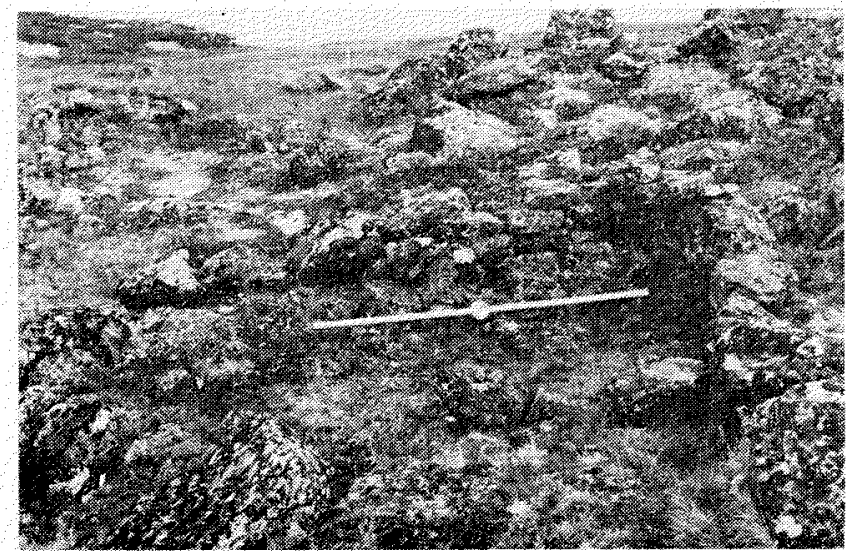

FIG. 6. Structure no. 6, Group 2 site, Deception Bay. Note the four layers of stone behind the surveying staff and the dividing wall in front. Photograph by A. Fincham. 
man-positioned stones and in caches. Bones from structure no. 10 have been dated to $620 \pm 80$ years ago (Gakushuin University, Japan, laboratory no. 1,036). The cracked animal bones were found pushed into the "house" wall crevices for some unknown reason, possibly to stop draughts. They consist of walrus (Odobenus rosmarus), caribou (Rangifer $\mathrm{sp}$.), polar bear (Ursus maritimus), arctic hare (Lepus arcticus) and a species of deer or elk - probably Cervus canadensis, the wapiti (see below and Appendix 1). A jaw of a polar bear was found in a cache north of structure no. 7 , though it was so encrusted with lichens as to be hardly distinguishable from the rocks. In another cache (near structure no. 14) all the bones were of caribou.

Charcoal from soil at a depth of $20-30 \mathrm{~cm}$ above fire-blackened bedrock on the outside of structure no. 6 at nine metres above Lac Duquet yielded a radiocarbon age of $330 \pm 100$ years ago (Yale University, laboratory no. 1717). Though this is probably on the young side because of slight contamination by modern organic acids, it suggests that the site was occupied until at least 1600 A.D. The radiocarbon-dated bones of caribou and arctic hare from structure no. 10 are probably nearer the age of the original 'settlement'. It must, however, be borne in mind that radiocarbon dates on bone from Arctic regions might err slightly on the old side (personal communication, Dr. K. Kigoshi, Gakushuin University, Japan). Hence the dates suggest that the site was occupied continuously or intermittently 400-600 years ago.

\section{Group 3}

This occurs on another rock drumlin one kilometre to the north of Groups 1 and 2 . I first saw the site in 1962, and from the occurrence of artefacts within the stone structures it is obvious that it had never been disturbed by modern Europeans since last it was used. This site was not mapped. The rock drumlin was once a

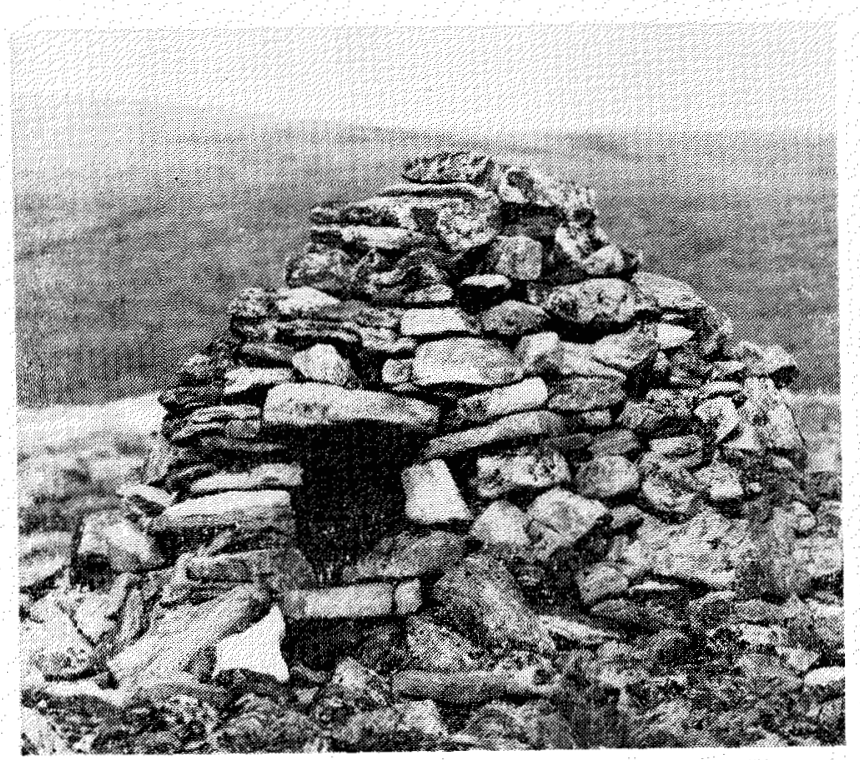

FIG. 7. Beehive structure, Group 3 site, Deception Bay. Two wood-and-feather artefacts were found inside it by the author in 1962. Photograph by G. Barber. Scale: 2 m = $5.8 \mathrm{~cm}$ approx. 
rocky island, as it is surrounded by fossiliferous marine deposits nearly to its top, at about $\mathbf{3 0}$ metres above sea level. Two beehive-shaped structures were found in a state of almost perfect preservation, and about 13 circular mounds two metres in diameter which were possibly the collapsed forms of similar structures. The best-preserved beehive structure (Fig. 7) is 2 metres high and 1.8 metres in diameter at the base, with a low, square entrance $45 \mathrm{~cm} \mathrm{x} 60 \mathrm{~cm}$, and a similarsized opening at the top. Other structures resembling coffins are possibly fall traps as they fit the description of such given by Low (1906). Between the circular mounds are collapsed tunnel-like structures.

In the area between Group 3 and Groups 1 and 2 are a few circular structures and possible caches.

On the floor of the beehive structure just referred to were two artefacts, each consisting of two pieces of planed wood $45 \mathrm{~cm} \times 3 \mathrm{~cm} \times 2 \mathrm{~cm}$ nailed together, with about eight green-dyed feathers between. These were partly buried in a litter, $3-5 \mathrm{~cm}$ deep, of moss remains, faeces and bones, while outside the structure was a disintegrating walrus skull. The oldest Sugluk Eskimo knew nothing about the ruins when asked in 1962. All he could suggest was that they may have been fall traps, with the wood-and-feather artefact being placed in winter across the rectangular opening on the roof to retain snow and to hold bait. Alternatively, they could have been food stores or even igloo-like shelters. The structures must be at least 100 years old. The amount of lichen encrustation of the ruins is not as great as with those of the other two groups.

\section{Discussion}

\section{Culture}

Although the beehive-shaped structures at Deception Bay have stone roofs, the rest of the ruins do not. It seems likely that the roofing of the latter was of another substance, probably skin. Alternatively, the existence of collapsed tunnel-like entrances to the oval structures could indicate that in the winter months the Group 1 structures were formed both of stones and snow blocks. This could explain the absence of buried skins and wooden or bone roof supports. The arrangement of stones inside the main foundations does not indicate a collapsed stone roof. Certainly the stone structures, especially the pentagonal, are more substantial than the normal Thule tent ring seen on the tundra. Drawings of skin tents in Ungava by Low (1898), however, show that in the nineteenth century some skin tents had fairly substantial stone walls. Another possibility is that either or both of the groups of structures were roofed with turf. The very thin soil around, and in the ruins of, Group 1 structures does not lend support to this hypothesis. The Group 2 ruins have, however, up to $30 \mathrm{~cm}$ of soil with large amounts of organic matter which may have once been roof turfs; but one would expect also to find remains of bone or wooden roof supports, unless all this material was removed by later bands of Eskimos.

The absence of artefacts in Groups 1 and 2 may be significant. Chert-like artefacts were found nearby, but it is not certain if they are associated with the stone structures or belong to an older culture. 
There are three possible explanations for the existence of the three groups of ruins:

1. They were all built by Eskimos of the early Thule culture, the three sites being built at different periods;

2. The three sites were built and occupied by peoples of different cultures at different times: Eskimos of Late Dorset or Thule culture, Norsemen from the Greenland colonies, or Indians (pentagonal structures);

3. The three sites were built by peoples of different cultures at the same time.

Of the three hypotheses, the first seems most likely. No definite Norse or Indian artefacts were found.

In support of the Norse hypothesis could be cited that:

1. Nailed and planed wooden objects exist in the beehive structures;

2. The pentagonal structures are similar in shape to, but smaller than, those of Norse ruins in the Isle of Man (British Isles) which used to be roofed with wooden struts and turfs;

3. The radiocarbon date of 1330 A.D. on cracked animal bones, pushed into crevices, fits in with the date of the abandonment of a Norse colony in western Greenland.

The absence, however, of objects of definite European type associated with the pentagonal structures gives this hypothesis very slim support. Nor do Indian artefacts occur. For this reason it seems probable that the structures were built by ancestors of the present-day Eskimos, but at different times in the evolution of their culture. The pentagonal ruins may have been built by Eskimos who had been in contact with the Norsemen in Greenland. The site seems to have been occupied to at least 1600 A.D., as is indicated by the age of charcoal from the site. The oval structures (Group 1) are probably the oldest, and the beehive structures (Group 3) the youngest. That Group 3 is younger is suggested by the good state of preservation of the nailed wood-and-feather objects and the smaller size of lichens on the stones. Also it is doubtful if the two remaining complete structures would have remained intact for over 500 years.

It is interesting to note that in 1884 Robert Bell (1885) found similar ruined rectangular and beehive structures on Nottingham Island. He thought then that the beehive structures must be at least 100 years old and that they had been "adapted for storing meat or as hiding places or 'stands' from which to kill game". He also found many shapeless heaps of stones, as at Deception Bay, and low rectangular walls built on the rocks facing Hudson Strait.

One puzzling aspect of the Group 2 site is the number of cracked animal bones found in the foundations and bones in caches. The latter could indicate either that originally the caches were full of meat which was left when the settlement was abandoned, and the flesh has since disintegrated; or else that the inhabitants were extremely tidy, and buried their rubbish in the only way possible on a rocky hill and in an area of permafrost. 


\section{Climate and general environment about 600 years ago}

A clue to the climate existing at the time the pentagonal structures were occupied about 600 years ago is provided by fossil peat and the occurrence of bones of elk (Cervus spp.). The elk was probably the wapiti (Cervus canadensis), which is no longer to be found in the Labrador-Ungava peninsula. At present it ranges over the Prairie Provinces and British Columbia, and small areas of Ontario. It is not usually regarded as an inhabitant of the tundra regions. About 600 years ago, it probably ranged much more widely than at present. The specimen in the archaeological site may well have been taken by a hunting party which moved south into the forest at a time when the mildness of the climate allowed the deer to penetrate much further north than at present. Records of woodland animals moving north to the Sugluk-Deception Bay area during periods of climatic amelioration in the twenties and thirties of the present century are to be found in the unpublished diaries of Hudson's Bay Company factors at Wolstenholme and Sugluk. For example, lynx were caught raiding fox traps in 1918 to the consternation of the Eskimos who had not seen them before.

In the valley of Rivière Saule $\left(74^{\circ} 06^{\prime} \mathrm{W}, 61^{\circ} 47^{\prime} \mathrm{N}\right)$, at the south end of Lac Françoise-Malherbe $28 \mathrm{~km}$ to the south-southeast of Deception Bay, fossil peat from a depth of $30 \mathrm{~cm}$ contains branches of tree willow (either Salix planifolia or Salix alaxensis) dated to $525 \pm 100$ years ago (National Physical Laboratory, no. 59). This fact suggests that the climate was similar to, or better than, that of the first half of this century when conditions permitted the initial growth of tree willows in a few sheltered canyons, 460 metres deep, near Deception Bay and Sugluk Inlet. The dated peat from immediately above the ice of an ice-cored peat mound yielded pollen of large amounts of spores of ferns and Lycopodium, most of which is L. annotinum. The latter may also be indicative of the close proximity of thicket communities at the time of its growth. It appears that a willow thicket, similar to one of the present time, existed in the Rivière Saule valley some 500 to 600 years ago. In the valley of the nearby Rivière Croix $\left(74^{\circ} 09^{\prime} \mathrm{W}, 61^{\circ} 46^{\prime} \mathrm{N}\right)$, fragments of alder wood exist in buried peat $90 \mathrm{~cm}$ below the surface of a river terrace. These may be of similar age to the dated peat.

Sphagnum peat grew and bore fruit at the south end of Sugluk Inlet about 1600-670 years ago, when the climate was mild (Bartley and Matthews 1969) a fact confirmed by the radiocarbon dating to $670 \pm 120$ years old (National Physical Laboratory, no. 125) of a sample from the top of buried Sphagnum peat in the area. At Village Bay $\left(56^{\circ} 05^{\prime} 31^{\prime \prime} \mathrm{N}, 61^{\circ} 24^{\prime} 29^{\prime \prime} \mathrm{W}\right)$ in northern Labrador I found, in 1971, a similar stratigraphy of interbedded organic and aeolian deposits as that at Sugluk with the upper layer of Sphagnum peat having a radiocarbon date of $620 \pm 60$ years old (Geological Survey of Canada, laboratory no. 1930). Sphagnum peat grew and bore fruit in northern Ungava in the mild period in the first half of the present century, but the climate has now deteriorated, and in 1973 I could find no spores in living Sphagnum, even in the Nain area at the edge of the Labrador forest.

During the mild period when the pentagonal structures were first occupied, there were abundant supplies of animals. Fossil evidence indicates that there were caribou, walrus, arctic hare, polar bear and, by a backward projection of present 
conditions, seal (Phoca spp.), white whale (Delphinapterus leucas), narwhale (Monodon monoceros), murre (Uria spp.), eider duck (Somateria spp.), ptarmigan (Lagopus spp.), geese (Branta spp. and Chen spp.) and fox (Alopex lagopus ungava and Vulpes fulva bangsi). At the present time northernmost Ungava is on the line of flight of geese migrating to and from Baffin Island.

If this settlement of over 15 oval and pentagonal structures was built at the same time and occupied over a long period, then a relatively large Eskimo community may have lived at the south end of Deception Bay at about the time of the European discovery of America, as compared with the scattered communities which were seen in northern Ungava by Low (1898). Such a large community could have existed only if land animals, such as caribou, were plentiful, a situation which is most likely to have existed during a period of climatic amelioration.

\section{VALLON-DES-RUINES SITE}

Above the narrow entrance to an unnamed valley west of Cape Gobin that I named Vallon-des-Ruines $\left(62^{\circ} 27^{\prime} 30^{\prime \prime} \mathrm{N}, 76^{\circ} 30^{\prime} \mathrm{W}\right)$ I located in 1962 stone structures thought by the Eskimos to have been built by the "Tunit", a legendary race of tall people. I only made a cursory examination of the site for half a day because of the gale force wind channelled down the valley threatening to capsize the Peterhead boat anchored off-shore.

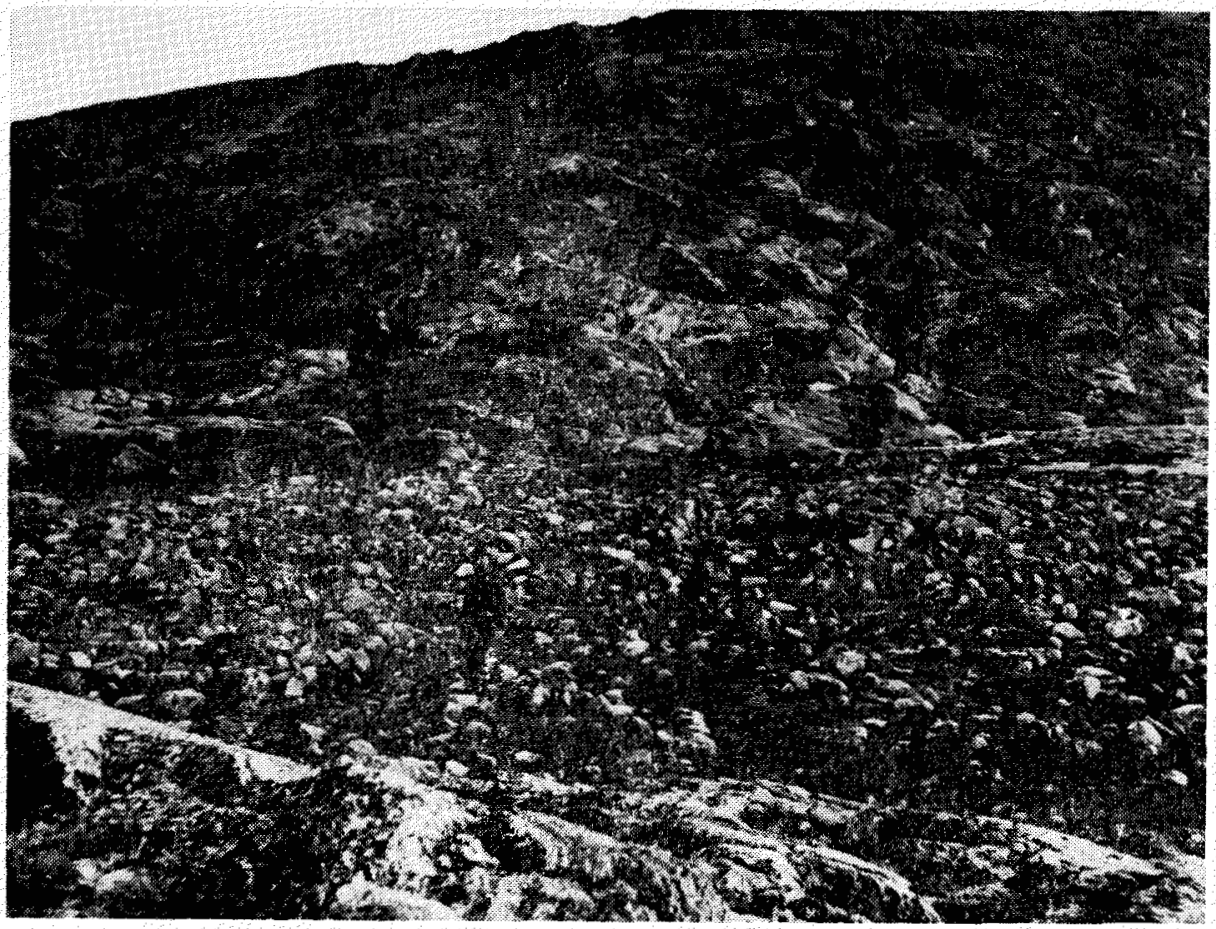

FIG. 8. "Vallon-des-Ruines" site. The sea is about 100 metres to the left (north), and to the right (south) is the lake at 17 metres above sea level. Note the two layers of large stones of some of the circular structures. Photograph by the author. 


\section{Regional setting}

The spectacular steep-sided valley is a former fiord raised above the sea by isostatic uplift of the land. It is separated from the adjacent fiord (Fiord Refuge) to the west by a narrow arête $\mathbf{4 5 0}$ metres high. It is terminated in the south by a 300-metre-high cliff down which a waterfall tumbles from the 450-metre plateau. The floor of the valley is occupied by two elongated lakes at 17 metres and 93 metres above sea level which are the sites of former ice-gouged basins dammed by rock bars and glacial moraines. The northern end of the valley and the 17-metre lake are separated from the sea by a granite-gneiss wave-cut platform covered with boulders and at an average elevation of 25 metres above sea level. The ruins are on its gently sloping (less than $3^{\circ}$ ) landward side and therefore at an elevation similar to the Group 1 site at Deception Bay. They cover an area of about $0.25 \mathrm{~km}^{2}$ between the lake at 17 metres and the top of the rock bar (Fig. 8).

\section{Archaeological remains}

The oval and circular stone structures, approximately 30 in number, are similar to those of Group 1 at Deception Bay, being up to four metres in diameter, with stone walls up to 0.7 metres high. The man-moved stones encrusted with lichen are up to one metre long, mostly glacial erratics of granite-gneiss, but some appear to have been roughly shaped by man. No artefacts were found at the site.

\section{Discussion}

The wave-cut platform on which the ruins partly occur can be correlated with the Lower Tunit Beach deposits (see Matthews 1967) at 20 metres above sea level, but it is doubtful if the settlement existed at the time of formation of the strandline about 5,500 years ago or the Dorset Culture site on Sugluk Island dated tentatively by Taylor (1957) as 2,000 to 2,500 years old.

At the present time the raised fiord is an extremely inhospitable place with no bushes for fuel and with violent winds channelled down the valley making landing and launching of boats from the exposed rock platform into Hudson Strait difficult. The site when occupied by man must have had a more favourable climate in summer than at the present time, and the sea must have been at a higher level relative to the land to allow use of kayaks. Presence of bones and teeth, not covered with lichens, of narwhale (Monodon monoceros), walrus (Odobenus rosmarus), polar bear (Ursus maritimus) and white whale (Delphinapterus leucas) on a nearby sheltered beach indicates that these animals were once common in the area and could have provided much food for the Eskimo.

\section{THE SCULPIN ISLAND SITE}

The site was examined in 1939, and described in detail by Tanner (1941) and Wenner (1947). Tanner shows diagrams and photographs of the ruins and carved wood artefacts. Wenner (1947) analysed the pollen in peat from within one of the structures. In 1971, I visited the site for one day collecting samples of wood, bone and basal peat from inside the stone structures for radiocarbon dating to try and determine the date of their occupation. Samples of whale vertebrae 
partly buried in gravel and overgrown with plants were collected from skeletons 300 metres north of the ruins and one metre above sea level. A whale vertebra resting on the walls of one structure was probably left by the 1939 expedition. The buried whale bones were later found to be too disintegrated and contaminated with modern roots and organic acids to be dated.

\section{Regional setting}

Sculpin Island $\left(56^{\circ} 48^{\prime} \mathrm{N}, 61^{\circ} 16^{\prime} \mathrm{W}\right)$ lies off the east coast of South Aulatsivik Island. It is in an extremely inhospitable area with, in August 1971, icebergs stranded off-shore. Its vegetation is sparse, consisting mainly of grasses, sedges, and a few prostrate dwarf willow (Salix spp.) and dwarf birch (Betula glandulosa) bushes, none taller than one metre. Inland, in sheltered canyons away from the influence of the cold Labrador current, there is one of the tallest and most luxuriant forests in the whole of the Labrador-Ungava Peninsula, with spruce trees up to 22 metres, and paper birch (Betula papyrifera) up to 12 metres tall (Matthews 1972), and fruits such as raspberry (Rubus idaeus), squashberry (Viburnum edule) and skunkcurrant (Ribes glandulosum).

\section{Archaeological remains}

There are two groups of stone foundations situated about one metre above present-day sea level. On cobbly raised storm beaches on the western side of the island are rectangular, pentagonal and elliptical dwellings. Further east, on a

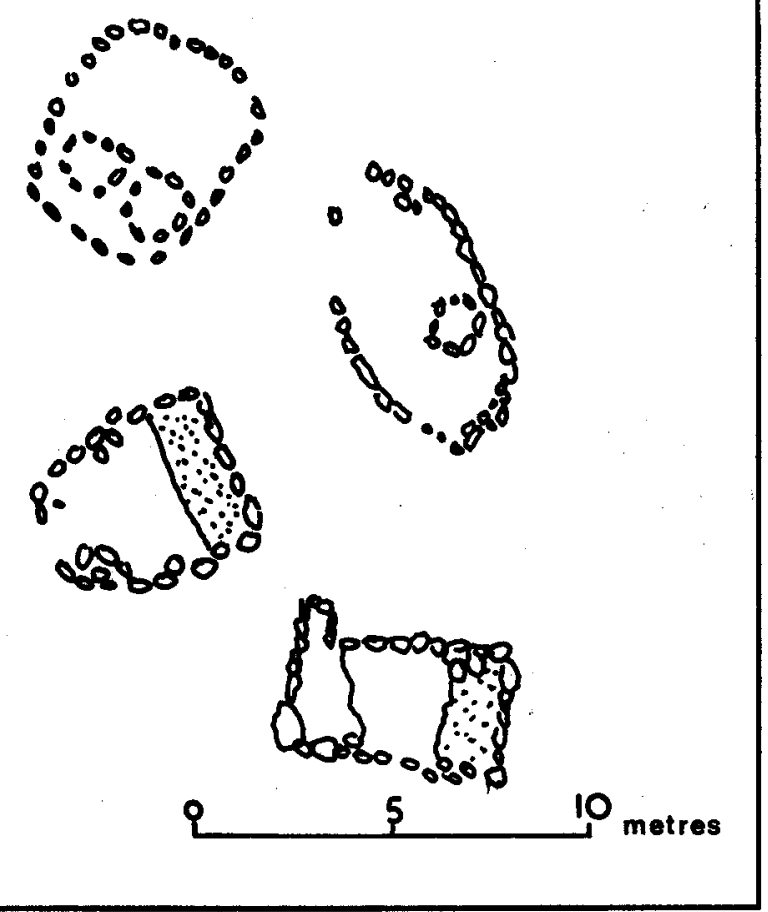

FIG. 9. Plan of typical foundations on Sculpin Island. Reproduced from Tanner 1941. 


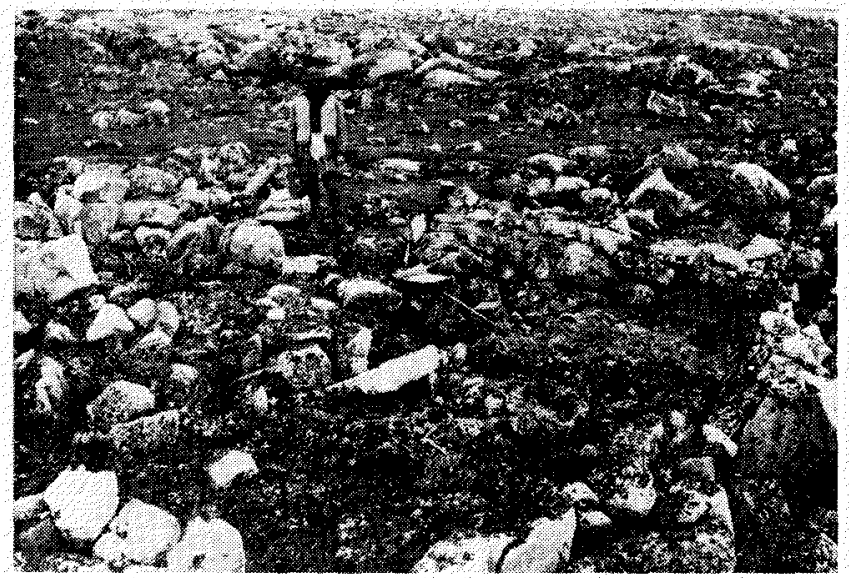

FIG. 10. Rectangular ruins at Sculpin Island. Photograph by the author.

gravelly sand beach, are Eskimo tent rings covered with lichens and other vegetation. Scattered on the exposed bedrock behind the ruins are more modernlooking stone wall 'windbreaks', little covered with lichens. The average dimensions of the largest rectangular structures are $2.1 \mathrm{~m} \mathrm{x} 4.5 \mathrm{~m}$ (see Figs. 9 and 10). The interior has a dividing arrangement of stones, and one structure has a porch-like projection. All the stones have lichens growing on them, but there are very few on one of the best preserved walls which is nearly 0.6 metres high. Inside the rectangular structure with a "porch" there is $15 \mathrm{~cm}$ of gravelly peat covered with tundra vegetation, mainly Empetrum and dwarf willow. Within the crevices of a few of the structures are small pieces of animal bone and wood.

A sample of basal organic soil resting on the floor of the best preserved rectangular structure with "porch" was dated to $105 \pm 75$ years ago (Japan Isotopes Corporation, laboratory no. 1,559). This errs on the young side as there was slight contamination by modern minute roots and organic acids. The pieces of bone and wood from the crevices were too small and contaminated with modern organic acids to be radiocarbon dated.

\section{Discussion}

It is apparent that the site has been disturbed by Eskimos or Europeans since its abandonment. The existence of only a few lichens on the tallest wall of the rectangular foundation with "porch" may suggest that it was rebuilt for some unknown reason. The overall general impression of the age of the structures is that they are younger than the foundations at Deception Bay where every stone and bone is heavily encrusted with lichens. This is possibly borne out by the radiocarbon date on organic soil from inside the dwelling. The presence of almost complete skeletons of whales nearby suggests that this mammal may have made an important contribution to the economy of the Sculpin people typical of the Thule culture. It is surprising that few other bones of land and sea animals were found. A hundred and fifty years ago, caribou (Rangifer sp.), black bear (Euarctos americanus), porcupine (Erethizon dorsatum), seal (Phoca spp.), Labrador duck (Camptorhynchus labradorius) - now extinct everywhere-eiderduck (Somateria 
spp.), geese (Branta spp. and Chen spp.), flightless great auk (Plautus impennis) - now extinct - and other species of animals would have been abundant.

Wenner (1947) stated that the "minor discoveries of material showing signs of human workmanship ... prove the settlement was Eskimo", but that the shape of the foundations was influenced by Europeans. He examined the pollen content in the humose soil which continued under the foundations. Pollen mostly occurred in the lowest part. It decreased towards the surface, while the amount of animal hair increased. In the undecomposed Empetrum layer there were no hairs. Wenner suggests that the hair came from skins laid on the floor of the cabins; but equally they could have come from caribou skins used as roof covering.

As neither the Moravians nor the Eskimos knew who had built the structures, they must be at least 150 years old. It is surprising that the Moravians do not have a record of such a settlement, if it was occupied after they moved into the Nain area in 1771 .

\section{CONCLUSIONS}

It would appear that all the ruins described at Deception Bay and Sculpin Island were built less than 1,500 years ago, and abandoned more than 150 years ago. The pentagonal and rectangular ruins at both sites are similar in size and shape, although those at Sculpin Island are more rectangular, perhaps because the Deception Bay pentagonal ruins were built on a boulder-strewn slope, whereas those at Sculpin Island are on a cobbly, flatter storm beach. They both also occur near the former sea level. At Deception Bay this was about 10 metres above present sea level, while at Sculpin Island it was only 0.6-1.0 metres above. This difference may reflect the different rates of isostatic rise of the land, if the ruins are of similar age. At Deception Bay the land is continuing to rise (Matthews 1967), but in the Nain area of Labrador uplift appears to have ceased. Alternatively, the difference in height above sea level could indicate that the sites are of different age. If they are of the same culture, it is doubtful if this was Norse; it is more likely that the ruins were built at some point in time by Eskimos who had been in contact with Europeans - ones from the Norse Greenland colonies, Basque fishermen or later visitors - as there were nailed and planed wood-andfeather artefacts, and divided rooms built partly of hewn stone at Deception Bay, and at Sculpin Island there was planed and chiselled wood. Moreover, at both sites the pentagonal foundations and room divisions are reminiscent of European influence. Other features are dissimilar; namely, the oval ruins (Group 1) above the pentagonal ones (Group 2) at Deception Bay; the beehive-shaped "foxtraps"; the occurrence of numerous cracked animal bones in crevices of the pentagonal ruins at Deception Bay. The existence of whale vertebrae (probably of the sperm whale) suggests that whale formed an important part of the diet of the Sculpin Island people as in the Thule culture (see McGhee 1974) compared with caribou, walrus, polar bear and arctic hare of the "Deception Bay culture" (indicated by the Group 2 foundations).

The similar oval and circular structures at Deception Bay (Group 1) and those of Vallon-des-Ruines may be older than the rectangular and pentagonal structures 
as they exist at a higher elevation, and could have been occupied by Eskimos of a late Dorset culture when the sea was up to 15 metres above its present level. The beehive structures (Group 3) at Deception Bay are probably less than 300 years old.

Despite the rejection of the idea that Deception Bay pentagonal and rectangular buildings were built by Norsemen, it is interesting to speculate on who, 600 years ago, occupied divided rectangular buildings and who cracked animal bones, presumably to extract the marrow.

\section{ACKNOWLEDGEMENTS}

The work on this paper which was in part contributory towards a doctoral dissertation awarded by McGill University, Montreal, Canada, was supported by grants from the Royal Society of London; the Arctic Institute of North America; Leeds University, England; the Royal Geographical Society, and the British Association. I thank the members of my 1962 field team, the members of the 1965 Leeds University Arctic Ungava Expedition - especially Dr. S. Hicks (née Phillips) and A. Fincham - and of the 1971 Labrador Expedition - especially T. M. Davies - for their help; Dr. D. D. Bartley of Leeds University for pollen analyses; C. B. Denton, Department of Archaeology and Anthropology, Cambridge University, for identification of human bones; and Judith E. King, Department of Zoology, British Museum, for identification of animal bones. Radiometric dates were determined by the National Physical Laboratory, England; Japan Isotopes Corporation, Tokyo; Dr. Kunihiko Kigoshi, Gakushuin University, Japan, and Dr. M. Stuiver, Yale University Radiocarbon Laboratory. I am indebted to A. Fincham, the cameraman on my 1965 expedition, for the photographs reproduced as Figs. 4 and 6, and to G. Barber of the 1975 Haberdashers' Aske's Hatcham School Arctic Ungava Expedition for Fig. 7.

\section{REFERENCES}

BARTLEY, D. D. and MATTHEWS, B. 1969 . A palaeobotanical investigation of Postglacial deposit in the Sugluk area of northern Ungava. Review of Palaeobotany and Palynology, 9:45-61.

BELL, R. 1885. Observations on geology, mineralogy, zoology, and botany of the Labrador Coast, Hudson's Bay and Strait. Geological Survey of Canada, Annual Report, 18 (6): 207-29.

GATHORNE-HARDY, G. M. 1922. A recent journey to northern Labrador. Geographical Journal, 59: 153-69.

1932. Alleged Norse remains in America. Antiquity, 6: 420.

LEE, T. E. 1967a. Fort Chimo and Payne Lake, Ungava, Archaeology, 1965. Quebec: Université Laval, Centre d'Etudes Nordiques (Travaux Divers 20).

1967b. Archaeological investigations, Deception Bay, Ungava Peninsula, 1965. Anthropological Journal of Canada, 5 (3): 14-40.

1968. Archaeological Discoveries, Payne Bay Region, Ungava, 1966. Quebec: Université Laval, Centre d'Etudes Nordiques (Travaux Divers 27).

1969. Archaeological Findings, Gyrfalcon to Eider Islands, Ungava, 1968. Quebec: Université Laval, Centre d'Etudes Nordiques (Travaux Divers 27).

LOW, A. P. 1898. Report of an exploration of part of the south shore of the Hudson Strait and Ungava Bay. Geological Survey of Canada, Annual Report, 9 (L) pp. 45-47.

1906. The Cruise of the Neptune. Report on the Dominion Government Expedition to Hudson Bay and the Arctic Islands, 1903-4. Ottawa: Government Printing Bureau.

MATTHEWs, B. 1967. Late Quaternary land emergence in northern Ungava, Quebec. Arctic, $20(3): 176-202$. 
413-9.

1972. Plant hunters on the Labrador coast. Geographical Magazine, 14 (6):

MATHIASSEN, T. 1928. Norse ruins in Labrador? American Anthropologist, 30: 569-79.

MAYCOCK, P. F. and MATTHEWS, B. 1966. An 'Arctic forest' in the tundra of northern Ungava, Quebec. Arctic, 19 (2): 114-44.

MCGHEe, R. 1974. The peopling of arctic North America. In: Ives, J. D. and Barry, R. G. (eds.), Arctic and Alpine Environments, London: Methuen, pp. 831-55.

PLUMet, P. 1969. Archéologie de l'Ungava: Le Probleme des Maisons Longues à Deux Hémicycles et Séparations Intérieures. Paris: Ecole Pratique des Hautes Etudes, Sorbonne (Contribution du Centre d'Etudes Arctiques et Finno-Scandinaves, no. 7).

TANNER, v. 1941. Ruinerna på Sculpin Island (Kanayoktok) i Nain's skägard, NewfoundlandLabrador. Ett formodat nordboviste fran medeltiden. Geografisk Tidsskrift, 44: 129-55.

TAYLOR, W. E. JR. 1957. Archaeological work in Ungava. Arctic Circular, 10 (2); 25-27.

WENNER, C.-0. 1947. Pollen diagrams from Labrador. Geografiska Annaler, 29 (1-2): 5-241.

\section{APPENDIX 1: Bones from Deception Bay}

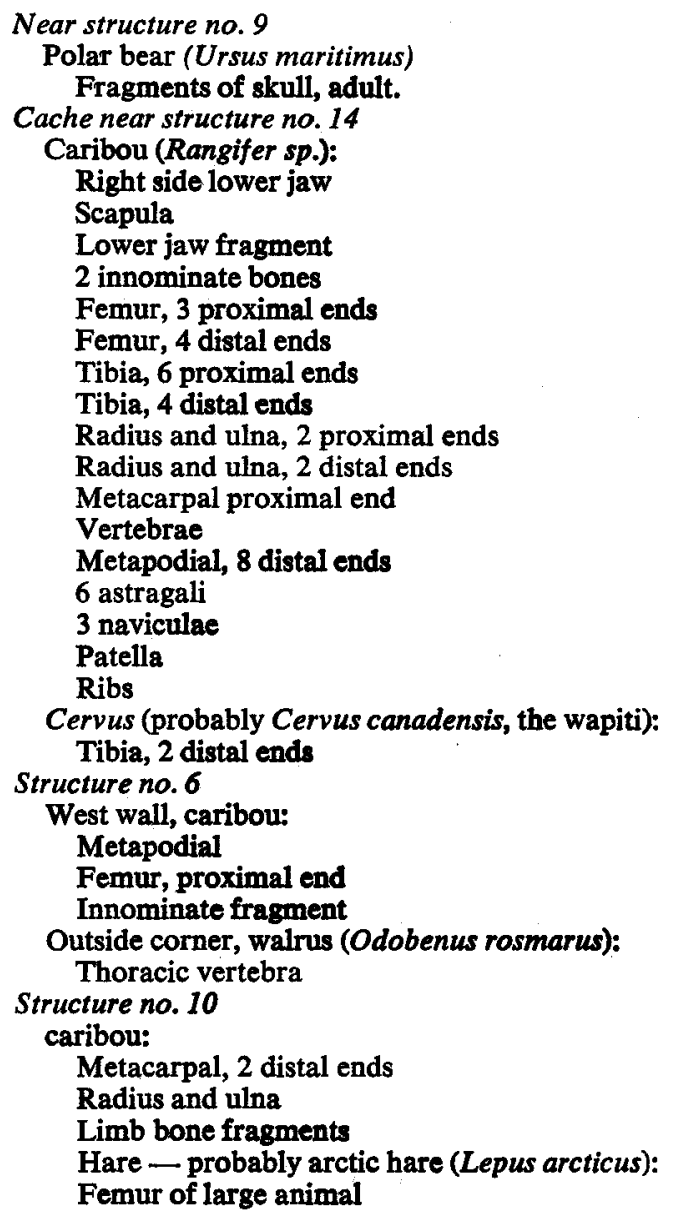


APPENDIX 2: Human remains from Group 1 site, structure no. 23, foundations, Deception Bay

C. B. Denston (Duckworth Laboratory of Physical Anthropology, Cambridge University, England) states in a report that the remains consist of a left humerus, a right ulna, a left patella, a left innominate bone, a sacrum, a left scapula, an atlas and a lumbar vertebra. The first three were intact, but the rest were in various stages of disintegration. The age at death was not easy to ascertain, but the individual was an adult male. The pubic symphysis of the innominate bone was eroded so that a determination of age based on the appearance of the symphysis was not possible. The sacrum features suggested that the individual was about 25-30 years old. The maximum length measurements were taken on the humerus and the ulna and these were applied to the Trotter and Glessner formulae for Europeans, producing a mean stature of about $160 \mathrm{~cm}$.

Lipping of the borders of the olecranon process of the ulna and the lipping of the inferior border of the body of the lumbar vertebra suggested the onset of osteo-arthritis. It is also possible that an anomaly of the sacrum had occurred. Features of the right ala and posterior half of the body of the sacrum suggested a partial sacralization of the fifth lumbar vertebra. 